\author{
Agnieszka GLUSZKO ${ }^{1}$ \\ Lucjan ŚLĘCZKA ${ }^{2}$
}

\title{
WERYFIKACJA STATECZNOŚCI ELEMENTÓW ŚCISKANYCH ZA POMOCĄ ANALIZY ZAAWANSOWANEJ
}

\begin{abstract}
Współczesne normy projektowania umożliwiają sprawdzanie nośności pojedynczych elementów poddanych ściskaniu w różny sposób. Klasyczne podejście to indywidualne sprawdzenie stateczności, przyjmując odpowiednie długości wyboczeniowe ustalone dla globalnej formy utraty stateczności. W celu wyznaczenia sił wewnętrznych stosowana jest wówczas najczęściej analiza I rzędu, sprężysta (LA), bez uwzględniania imperfekcji. Drugie podejście polega na uwzględnieniu podczas analizy wpływu globalnych imperfekcji przechyłowych i lokalnych łukowych i wykonaniu obliczeń według teorii II rzędu (GNIA). W takim przypadku indywidualne sprawdzanie stateczności poszczególnych elementów nie jest konieczne. Weryfikacja nośności ogranicza się do sprawdzenia obliczeniowych warunków nośności przekroju, z uwzględnieniem wyznaczonych $\mathrm{w}$ ten sposób sił wewnętrznych. W pracy przedstawiono porównanie oceny stateczności pojedynczych prętów oraz ramy portalowej przeprowadzone tymi metodami. Rozpatrywane w referacie elementy zostały zróżnicowane pod względem warunków podparcia, smukłości oraz rodzaju przekroju poprzecznego prętów. W przypadku ramy zastosowano stałą smukłość prętów, natomiast zmienną wartość obciążenia. Podano zależności pomiędzy zastosowaną analizą i modelami obliczeniowymi, a otrzymanymi rezultatami. Wyniki wskazują na znaczną, lecz nie całkowitą, porównywalność obu podejść obliczeniowych.
\end{abstract}

Słowa kluczowe: analiza I rzędu, analiza II rzędu, imperfekcje globalne i lokalne, nośność elementów ściskanych, rama portalowa

\section{Wprowadzenie}

Współczesne normy projektowania umożliwiają sprawdzanie stateczności pojedynczych elementów, poddanych ściskaniu, w różny sposób. W tym celu

\footnotetext{
${ }^{1}$ Autor do korespondencji; Agnieszka Głuszko, Politechnika Rzeszowska, Katedra Konstrukcji Budowlanych, ul. Poznańska 2, 35-084 Rzeszów, agluszko@prz.edu.pl

${ }^{2}$ Lucjan Ślęczka, Politechnika Rzeszowska, Katedra Konstrukcji Budowlanych, ul. Poznańska 2, 35-084 Rzeszów,sleczka@prz.edu.pl
} 
stosowane są odmienne modele obliczeniowe na użytek wyznaczenia sił wewnętrznych i wymiarowania ustroju konstrukcyjnego [1], [2].

Klasyczne podejście do oszacowania nośności elementów ściskanych osiowo to indywidualne sprawdzenie stateczności, przyjmując odpowiednie długości wyboczeniowe ustalone dla globalnej postaci wyboczenia. W celu wyznaczenia sił wewnętrznych stosowana jest wówczas najczęściej analiza I rzędu, sprężysta (LA) [3], bez uwzględniania imperfekcji. Ten sposób analizy i weryfikacji określany jest mianem AVA0 [1]. Zgodnie z zapisami normy PNEN 1993-1-1 [2] analizę pierwszego rzędu można stosować, jeśli przyrost efektów oddziaływań (najczęściej sił wewnętrznych) wynikający z efektów towarzyszących deformacjom nie wpływa istotnie na zachowanie się konstrukcji. Zgodnie z załącznikiem krajowym analizę pierwszego rzędu można stosować w przypadku układów nieprzechyłowych, a także jednokondygnacyjnych układów przechyłowych.

Drugie podejście polega na uwzględnieniu podczas analizy wpływu globalnych imperfekcji przechyłowych i lokalnych łukowych. Jeśli do wyznaczenia sił wewnętrznych zastosowana jest sprężysta analiza II rzędu, to indywidualne sprawdzanie stateczności poszczególnych elementów nie jest konieczne. Taką analizę określa się mianem GNIA [3], natomiast podejście obliczeniowe jako AVA2 [1]. Ocena stanu granicznego nośności polega na sprawdzeniu obliczeniowych warunków nośności przekroju elementu, z uwzględnieniem wyznaczonych w ten sposób sił wewnętrznych [2].

Podejście takie staje się coraz częstsze, wobec nieustannego rozwoju pakietów obliczeniowych, umożliwiających łatwe przeprowadzenie analizy konstrukcji według teorii II rzędu, z równoczesną łatwą możliwością zadawania imperfekcji globalnej i lokalnej. Jednocześnie brak jest informacji na temat porównywalności wyników oceny nośności uzyskiwanych tymi dwiema metodami, co jest istotne dla praktykujących inżynierów.

W pracy przedstawiono porównanie oceny stateczności elementów przeprowadzone przy użyciu powyższych metod. Rozpatrywane w referacie elementy zostały zróżnicowane pod względem warunków podparcia, smukłości oraz typu przekroju poprzecznego prętów. Oprócz analizy prętów pojedynczych o stosunkowo prostych schematach statycznych, rozważono także stateczność jednokondygnacyjnej ramy portalowej. Podano zależności pomiędzy zastosowaną analizą i modelem obliczeniowym a otrzymanymi rezultatami.

\section{Weryfikacja stateczności prętów}

\subsection{Przedmiot analizy}

Rozpatrzono zachowanie i poddano ocenie nośność pionowych prętów poddanych ściskaniu osiowemu. Analizowane elementy zostały podzielone na grupy zróżnicowane pod względem warunków podparcia, smukłości oraz typu 
przekroju poprzecznego, (Rys. 1 oraz Tablica 1 i 2). Przyjęto następujące schematy statyczne prętów: podparty obustronnie przegubowo (grupa A i C) oraz pręt wspornikowy (grupa B i D).

a)

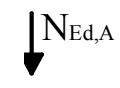

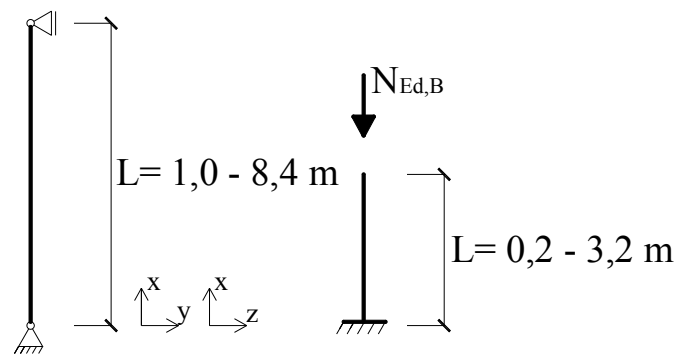

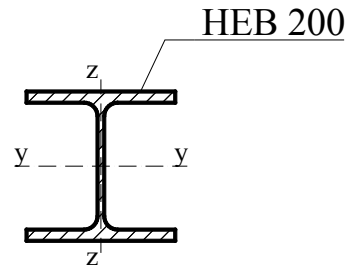

Grupa A

Grupa B

b)

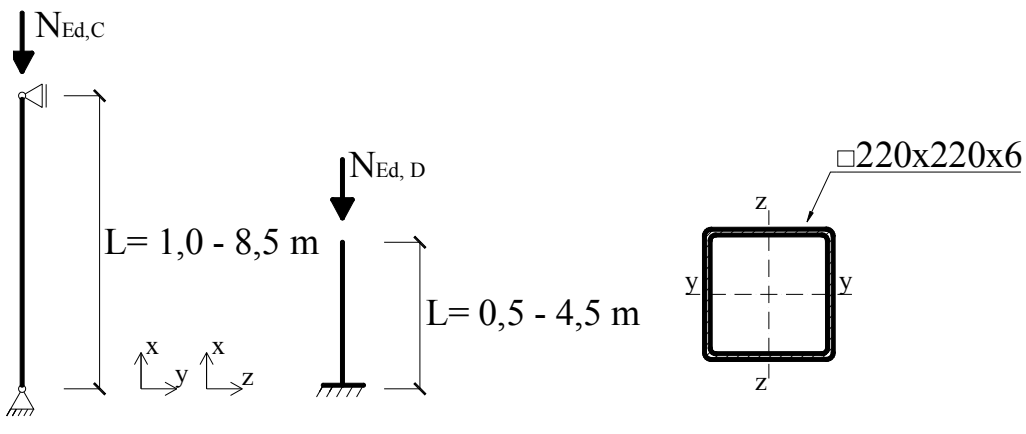

Grupa C

Grupa D

Rys. 1. Charakterystyka rozpatrywanych elementów: a) grupa A i B, b) grupa C i D (opis w tekście)

Fig. 1. The specification of considered elements a) group A and B, b) group C and D (description in the text)

Rozpatrzono dwa rodzaje przekrojów poprzecznych wykonanych ze stali gatunku S235. Były to kształtowniki HEB 200 (grupa A i B) oraz rura kwadratowa $\square 220 \times 220 \times 6$ (grupa $\mathrm{C}$ i D). W każdej z grup brano pod uwagę zmienną długość elementu, w celu zróżnicowania smukłości, (Tablica 1 i 2). Pręty zostały obciążone stałą wartością pionowej siły ściskającej, która wynosiła $\mathrm{N}_{\mathrm{Ed}, \mathrm{A}}=450 \mathrm{kN}$ (grupa A), $\mathrm{N}_{\mathrm{Ed}, \mathrm{B}}=700 \mathrm{kN}$ (grupa B), $\mathrm{N}_{\mathrm{Ed}, \mathrm{C}}=800 \mathrm{kN}$ (grupa C) oraz $\mathrm{N}_{\mathrm{Ed}, \mathrm{D}}=700 \mathrm{kN}$ (grupa D). 
Tablica 1. Rozpatrywane długości prętów o przekroju dwuteowym

Table 1 . The length of the analysed H-section elements

\begin{tabular}{|c|c|c|c|c|c|}
\hline \multicolumn{7}{|c|}{ Hrupa A } & \multicolumn{3}{c|}{ Grupa B } \\
\hline \multicolumn{3}{|c|}{ Gro 200 } \\
\hline $\mathrm{L}[\mathrm{m}]$ & $\overline{\lambda_{y}}$ & $\overline{\lambda_{z}}$ & $\mathrm{~L}[\mathrm{~m}]$ & $\overline{\lambda_{y}}$ & $\overline{\lambda_{z}}$ \\
\hline 1,0 & 0,13 & 0,21 & 0,2 & 0,05 & 0,08 \\
\hline 2,0 & 0,25 & 0,42 & 0,4 & 0,10 & 0,17 \\
\hline 3,0 & 0,37 & 0,63 & 0,6 & 0,15 & 0,25 \\
\hline 4,0 & 0,50 & 0,84 & 0,8 & 0,20 & 0,34 \\
\hline 4,4 & 0,55 & 0,92 & 1,0 & 0,25 & 0,42 \\
\hline 4,8 & 0,60 & 1,01 & 1,2 & 0,30 & 0,50 \\
\hline 5,2 & 0,65 & 1,09 & 1,4 & 0,35 & 0,59 \\
\hline 5,6 & 0,70 & 1,18 & 1,6 & 0,40 & 0,67 \\
\hline 6,0 & 0,75 & 1,26 & 1,8 & 0,45 & 0,76 \\
\hline 6,4 & 0,80 & 1,34 & 2,0 & 0,50 & 0,84 \\
\hline 6,8 & 0,85 & 1,43 & 2,2 & 0,55 & 0,92 \\
\hline 7,2 & 0,90 & 1,51 & 2,4 & 0,60 & 1,01 \\
\hline 7,6 & 0,95 & 1,60 & 2,6 & 0,65 & 1,09 \\
\hline 8,0 & 1,00 & 1,68 & 2,8 & 0,70 & 1,18 \\
\hline 8,4 & 1,05 & 1,76 & 3,0 & 0,75 & 1,26 \\
\hline & & & 3,2 & 0,80 & 1,34 \\
\hline
\end{tabular}

Tablica 2. Rozpatrywane długości prętów o przekroju zamkniętym kwadratowym

Table 2. The length of the analysed square sections elements

\begin{tabular}{|c|c|c|c|}
\hline \multicolumn{4}{|c|}{$\square \mathbf{2 2 0 \times 2 2 0 \times 6}$} \\
\hline \multicolumn{2}{|c|}{ Grupa C } & \multicolumn{2}{c|}{ Grupa D } \\
\hline $\mathrm{L}[\mathrm{m}]$ & $\bar{\lambda}$ & $\mathrm{L}[\mathrm{m}]$ & $\bar{\lambda}$ \\
\hline 1,0 & 0,12 & 0,5 & 0,12 \\
\hline 2,0 & 0,24 & 1,0 & 0,24 \\
\hline 3,0 & 0,37 & 1,5 & 0,37 \\
\hline 4,0 & 0,49 & 2,0 & 0,49 \\
\hline 5,0 & 0,61 & 2,5 & 0,61 \\
\hline 5,5 & 0,67 & 3,0 & 0,73 \\
\hline 6,0 & 0,73 & 3,5 & 0,86 \\
\hline 6,5 & 0,79 & 4,0 & 0,98 \\
\hline 7,0 & 0,86 & 4,2 & 1,03 \\
\hline 7,5 & 0,92 & 4,5 & 1,10 \\
\hline 8,0 & 0,98 & & \\
\hline 8,5 & 1,04 & & \\
\hline
\end{tabular}




\subsection{Metodyka postępowania}

Przeanalizowano dwie metody oceny stateczności elementów, zgodnie z normą [2] i [4].

Pierwsze podejście obliczeniowe (AVA0) polegało na wyznaczeniu sił wewnętrznych w prętach za pomocą analizy I rzędu, bez uwzględnienia imperfekcji. Weryfikacja nośności polega w tym przypadku na sprawdzeniu obliczeniowych warunków nośności przekroju oraz stateczności ogólnej.

Warunek nośności obliczeniowej przekroju przy ściskaniu sprawdzono z zależności:

$$
\begin{aligned}
& \frac{N_{E d}}{N_{c, R d}} \leq 1,0 \\
& N_{c, R d}=\frac{A \cdot f_{y}}{\gamma_{M 0}}
\end{aligned}
$$

gdzie: $\mathrm{N}_{\mathrm{Ed}}$ - obliczeniowa podłużna siła ściskająca,

$\mathrm{N}_{\mathrm{c}, \mathrm{Rd}}$ - obliczeniowa nośność przekroju na ściskanie, wyznaczona na podstawie klasy przekroju,

A - pole powierzchni przekroju poprzecznego,

$\mathrm{f}_{\mathrm{y}}-$ granica plastyczności stali,

$\gamma_{\mathrm{M} 0}$ - współczynnik częściowy stosowany przy rozpatrywaniu nośności przekroju.

Warunek stateczności polegał na rozpatrzeniu nośności na wyboczenie:

$$
\begin{aligned}
& \frac{N_{E d}}{N_{b, R d}} \leq 1,0 \\
& N_{b, R d}=\chi \frac{A \cdot f_{y}}{\gamma_{M 1}}
\end{aligned}
$$

gdzie: $\mathrm{N}_{\mathrm{b}, \mathrm{Rd}}-$ obliczeniowa nośność przekroju na ściskanie $\mathrm{z}$ uwzględnieniem wyboczenia względem osi y-y lub z-z,

$\chi$ - współczynnik wyboczenia,

$\gamma_{\mathrm{M} 1}-$ współczynnik częściowy stosowany przy sprawdzaniu stateczności elementu.

Współczynnik wyboczenia $\chi$ obliczano biorąc pod uwagę długość wyboczeniową w rozpatrywanej płaszczyźnie wyboczenia [5]. Wobec elementarnych 
schematów statycznych rozpatrywanych prętów przyjmowano $\mathrm{L}_{\mathrm{cr}}=1,0 \mathrm{~L}$ (grupa A i C) oraz $\mathrm{L}_{\mathrm{cr}}=2,0 \mathrm{~L}$ (grupa B i D). Brano pod uwagę krzywą wyboczenia „, dla dwuteownika HEB 200 przy wyboczeniu względem osi y-y, „c” dla dwuteownika HEB 200 przy wyboczeniu względem osi z-z, oraz krzywą „a” przy wyboczeniu względem obu osi przekroju dla kształtownika zamkniętego kwadratowego.

Obliczenia przeprowadzono dla każdej z rozpatrywanych smukłości prętów (Tablica 1 i 2). Dla każdego analizowanego przypadku wyznaczono współczynnik wykorzystania nośności $\eta_{\mathrm{AVA}}$, który był większą wartością z lewych stron nierówności (1) i (3). W przypadku grupy A i B współczynnik taki wyznaczano dwukrotnie rozpatrując wykorzystanie nośności pręta przy wyboczeniu względem osi y-y $\left(\eta_{\mathrm{AVA} A, y}\right)$ oraz przy wyboczeniu względem osi $z-z$ $\left(\eta_{\mathrm{AVA} 0, \mathrm{z}}\right)$.

Drugim podejściem obliczeniowym (AVA2) było uwzględnienie globalnej imperfekcji przechyłowej $\phi$ i lokalnej łukowej o strzałce wstępnego wygięcia $\mathrm{e}_{0}$ oraz przeprowadzenie analizy sprężystej według teorii II rzędu.

Imperfekcje globalne i lokalne przyjęto na podstawie zalecenia z załącznika krajowego do [2]. Według tego założenia imperfekcje lokalne przyjęto niezależnie dla prętów ściskanych ustroju, o postaci odnoszącej się do pierwszej formy wyboczenia elementu swobodnie podpartego i o strzałce wygięcia zależnej od krzywej wyboczeniowej, a niezależnej od smukłości elementu. Imperfekcje globalne przyjęto niezależnie od imperfekcji lokalnych i o wartości zależnej od geometrii ustroju. Interpretację graficzną rozpatrzonych imperfekcji przedstawiono na rys. 2. Obliczeniowe wartości wstępnych imperfekcji łukowych uzależnione były od rodzaju przekroju poprzecznego kształtownika i długości pręta. Miały one następujące wartości:

a) $e_{0}=\frac{L}{250}$, grupa $\mathrm{A}$ i $\mathrm{B}$, wyboczenie względem osi y-y, (krzywa wyboczenia „b")

b) $e_{0}=\frac{L}{200}$, grupa A i $\mathrm{B}$, wyboczenie względem osi z-z, (krzywa wyboczenia ,c")

c) $e_{0}=\frac{L}{300}$, grupa $\mathrm{C}$ i D, wyboczenie względem obu osi przekroju, (krzywa wyboczenia ,a") gdzie L to długość teoretyczna pręta [2], [5].

Do przeprowadzenia analizy według teorii II rzędu wykorzystano program komputerowy Autodesk Robot Structural Analysis [6].

Ponieważ efekty II rzędu i odpowiednie imperfekcje w poszczególnych elementach zostały całkowicie uwzględnione, to w takim przypadku indywidualne sprawdzanie stateczności elementów nie jest konieczne. 
Przy weryfikacji stanu granicznego nośności rozpatrzono tylko warunki nośności obliczeniowej przekroju, dla sił wewnętrznych otrzymanych podczas analizy, (rys. 2).

a)
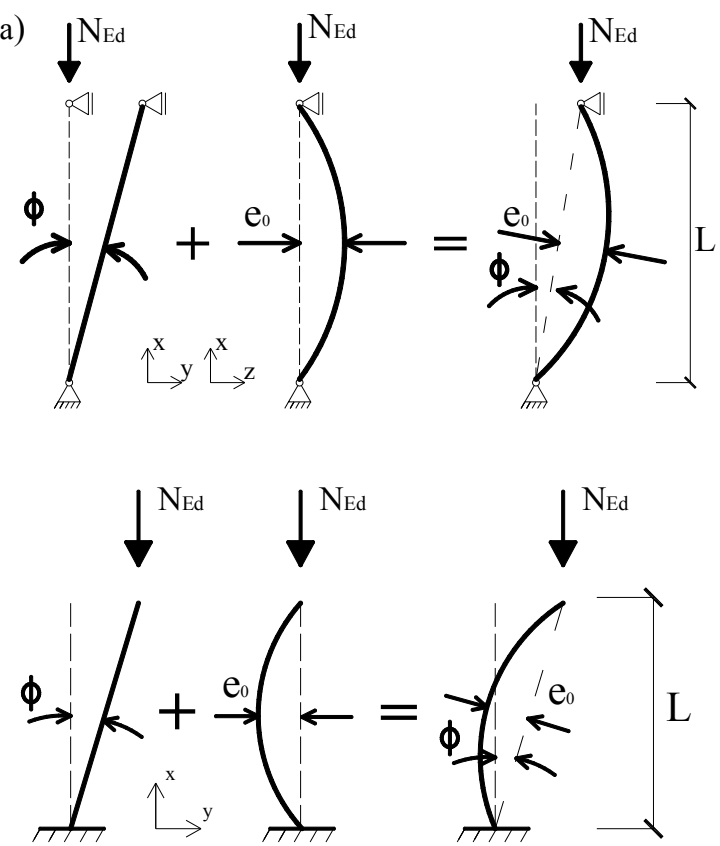

b)
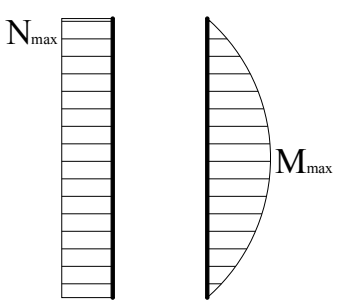

(NE) $\mathrm{M}_{\mathrm{E}}$

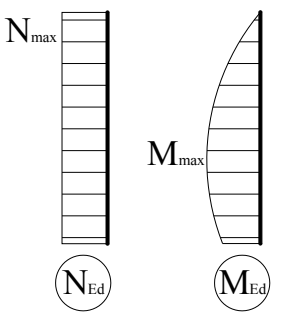

Rys. 2. Analiza II rzędu prętów a) imperfekcje globalne i lokalne, b) wykresy sił wewnętrznych

Fig. 2. The second-order analysis a) global and local imperfections, b) internal forces diagram

Oprócz warunku nośności przekroju przy ściskaniu (1) sprawdzono warunki nośności przekroju przy zginaniu (5) oraz warunki nośności przekroju przy zginaniu z uwzględnieniem siły podłużnej (6).

$$
\begin{aligned}
& \frac{M_{E d}}{M_{c, R d}} \leq 1,0 \\
& \frac{M_{E d}}{M_{N, R d}} \leq 1,0
\end{aligned}
$$

gdzie: $\mathrm{M}_{\mathrm{Ed}}$ - obliczeniowy moment zginający wynikający z przeprowadzonej analizy, $\mathrm{M}_{\mathrm{c}, \mathrm{Rd}}$ - obliczeniowa nośność przekroju przy zginaniu (7), 
$\mathrm{M}_{\mathrm{N}, \mathrm{Rd}}$ - zredukowana nośność plastyczna przy zginaniu z uwzględnieniem wpływu siły podłużnej $\mathrm{N}_{\mathrm{Ed}}((8)$ lub (12)).

Obliczeniową nośność przekroju przy zginaniu wyznaczano z zależności:

$$
M_{c, R d}=\frac{W_{p l} \cdot f_{y}}{\gamma_{M 0}}
$$

Natomiast nośność przekroju przy zginaniu z siłą podłużną wyliczano z zależności uwzględniających płaszczyznę zginania i rodzaj kształtownika. W przypadku dwuteowników walcowanych:

$$
\begin{aligned}
& M_{N, y, R d}=M_{p l, y, R d}(1-n) /(1-0,5 a) \leq M_{p l, y, R d} \\
& M_{N, z, R d}=M_{p l, z, R d}\left[1-\left(\frac{n-a}{1-a}\right)^{2}\right] \\
& a=\left(A-2 b \cdot t_{f}\right) / A \leq 0,5 \\
& n=\frac{N_{E d}}{N_{p l, R d}}
\end{aligned}
$$

W przypadku kształtowników rurowych prostokątnych:

$$
\begin{aligned}
& M_{N, y, R d}=M_{p l, y, R d}(1-n) /\left(1-0,5 a_{w}\right) \leq M_{p l, y, R d} \\
& M_{N, z, R d}=M_{p l, z, R d}(1-n) /\left(1-0,5 a_{f}\right) \leq M_{p l, z, R d} \\
& a_{w}=(A-2 b \cdot t) / A \leq 0,5 \\
& a_{f}=(A-2 h \cdot t) / A \leq 0,5
\end{aligned}
$$

Dla każdego analizowanego przypadku wyznaczono współczynnik wykorzystania nośności $\eta_{\mathrm{AVA} A}$, który był większą wartością z lewych stron nierówności (1), (5) i (6). W przypadku grupy A i B współczynnik taki wyznaczano 
dwukrotnie rozpatrując wykorzystanie nośności pręta przy wyboczeniu względem osi y-y $\left(\eta_{\mathrm{AVA} 2, \mathrm{y}}\right)$ oraz przy wyboczeniu względem osi z-z $\left(\eta_{\mathrm{AVA}, \mathrm{z}}\right)$.

\subsection{Wyniki}

Porównanie otrzymanych rezultatów przedstawiono na rys. 3 i 4 . Na osi odciętych odkładano wartości współczynników wykorzystania nośności otrzymanych według podejścia AVA0, natomiast na osi rzędnych wartości współczynników według podejścia AVA2.

a)

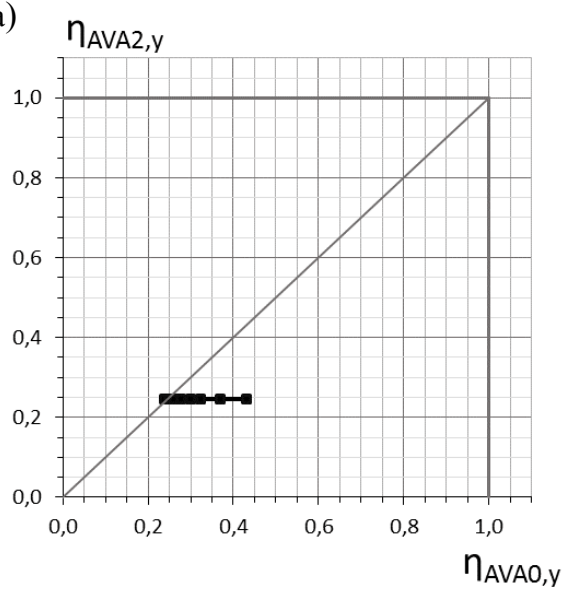

b)

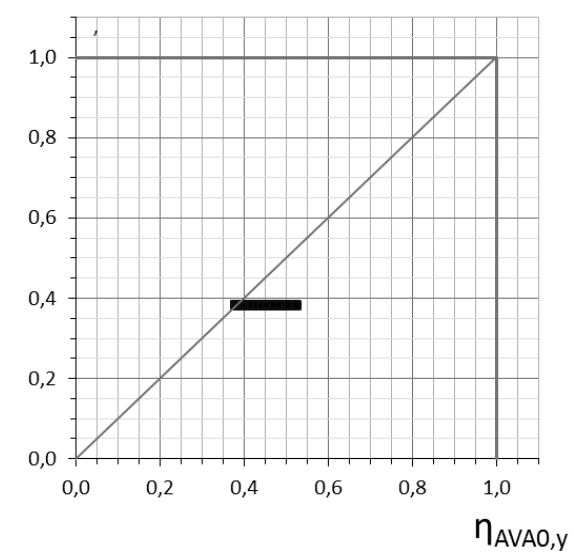

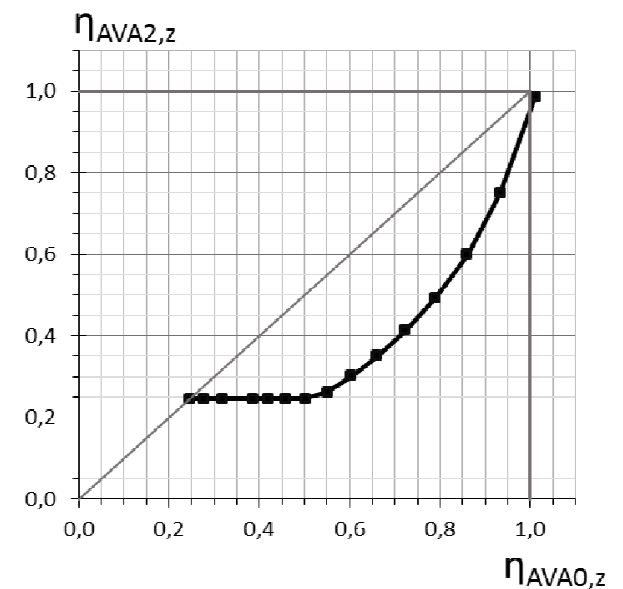

$\eta_{A V A 2, z}$

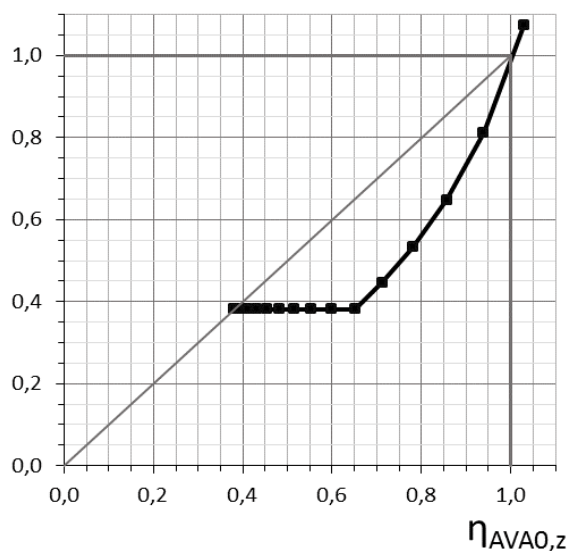

Rys. 3. Porównanie otrzymanych wyników: a) grupa A, b) grupa B (opis w tekście)

Fig. 3. Comparison obtained results: a) group A, b) group B (description in the text)

W przypadku, gdy rezultaty osiągane obiema metodami są identyczne, punkty odpowiadające takim współrzędnym (poszczególnym przypadkom kolejnych analiz) układają się wzdłuż linii nachylonej pod kątem $45^{\circ}$, wychodzą- 
cej z początku układu współrzędnych. Odchylenie wyników od tej linii świadczy o zróżnicowaniu rezultatów uzyskanych tymi dwoma podejściami obliczeniowymi.

a)

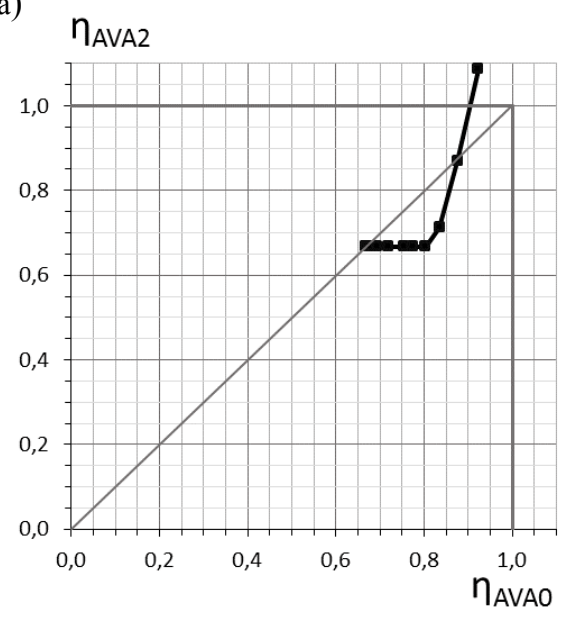

b)

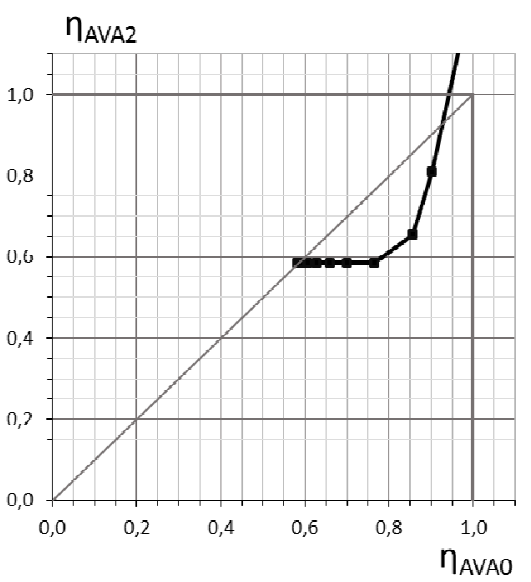

Rys. 4. Porównanie otrzymanych wyników: a) grupa C, b) grupa D (opis w tekście)

Fig. 4. Comparison obtained results: a) group C, b) group D (description in the text)

We wszystkich grupach, w przypadku podejścia obliczeniowego AVA0, decydujący o nośności był warunek stateczności (3). W podejściu obliczeniowym AVA2 w przypadku prętów o smukłości nieprzekraczającej $\bar{\lambda}=1,09$ (grupa A), $\bar{\lambda}=0,92$ (grupa B), $\bar{\lambda}=0,73$ (grupa C), $\bar{\lambda}=0,86$ (grupa D), decydował warunek nośności przy ściskaniu (1), natomiast dla elementów o większej smukłości decydujący był warunek nośności przekroju przy zginaniu z uwzględnieniem siły podłużnej (6).

Niemal całkowitą zgodność obu podejść otrzymano w przypadku prętów dwuteowych, przy osiągnięciu przez nich około $100 \%$ obliczeniowej nośności krytycznej. Przy mniejszym poziomie wytężenia, podejście obliczeniowe AVA2 dawało niższe rezultaty, nawet do $35 \%$.

W przypadku prętów wykonanych z rur kwadratowych zgodność uzyskanych rezultatów przy $100 \%$ poziomie obliczeniowego wytężenia była mniejsza. Przy tym wytężeniu podejście obliczeniowe AVA2 dawało rezultaty szacowania obliczeniowej nośności o $16 \%$ większe. 


\section{Weryfikacja stateczności układu ramowego}

\subsection{Przedmiot analizy}

W drugiej części pracy rozpatrzono ramę portalową, jednonawową o rozpiętości $8 \mathrm{~m}$ i wysokości $6 \mathrm{~m}$. Przyjęto schemat statyczny, w którym słupy oparto przegubowo w fundamencie, natomiast rygiel jest sztywno połączony ze słupami, (rys. 5). Na elementy konstrukcyjne wybrano przekroje zamknięte kwadratowe $\square 220 \times 220 \times 6$ ze stali gatunku S235. Układ obciążono dwiema siłami skupionymi przyłożonymi w osi podłużnej słupa. W obliczeniach przyjmowano zmieniającą się wartość siły, w przedziale $\mathrm{N}_{\mathrm{Ed}}=25 \div 340 \mathrm{kN}$.
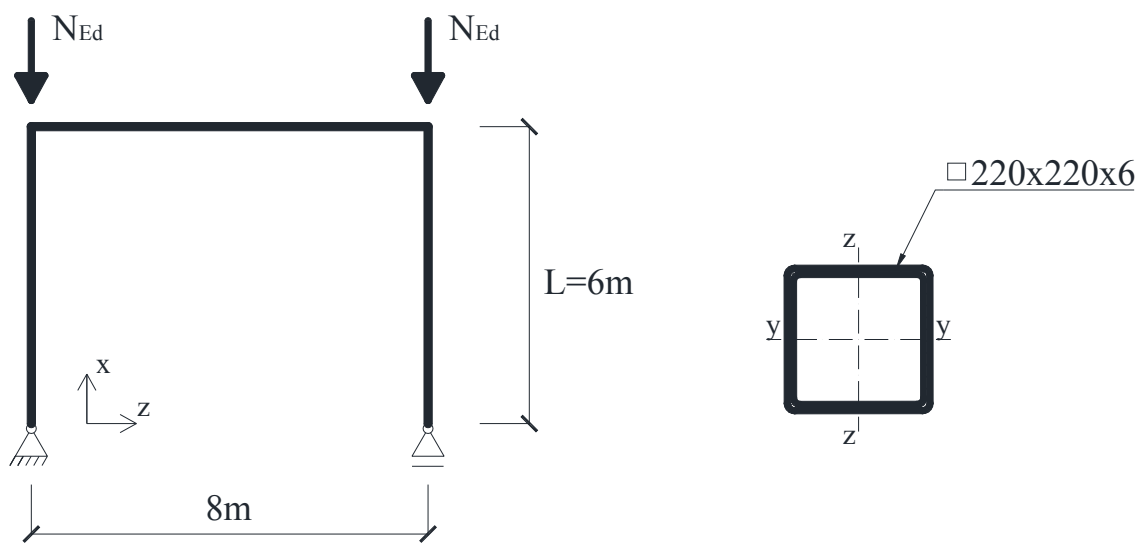

Rys. 5. Schemat statyczny analizowanej ramy portalowej

Fig. 5. Static scheme of analysed portal frame

\subsection{Metodyka postępowania}

Metodyka postępowania była podobna to tej opisanej w przypadku analizy pojedynczych prętów.

Rozpatrzono zachowanie konstrukcji tylko w płaszczyźnie układu ramy. W podejściu AVA0 długość wyboczeniowa słupów została wyznaczona za pomocą programu komputerowego ARSAP [6] i wynosiła $\mathrm{L}_{\mathrm{cr}}=2,48 \mathrm{~L}$. W podejściu AVA2 rozpatrzono imperfekcję przechyłową ramy i lokalne imperfekcje łukowe słupów, pokazane na rys. 6 .

Rozpatrzona wartość wstępnego przechyłu ramy wynosiła $\phi=3,5 \cdot 10^{-3} \mathrm{rad}$, natomiast wstępna strzałka wygięcia imperfekcji lokalnej słupów $\mathrm{e}_{0}=\mathrm{L} / 300=20 \mathrm{~mm}$. Weryfikacja nośności miała charakter opisany $\mathrm{w}$ punkcie 2.2. 


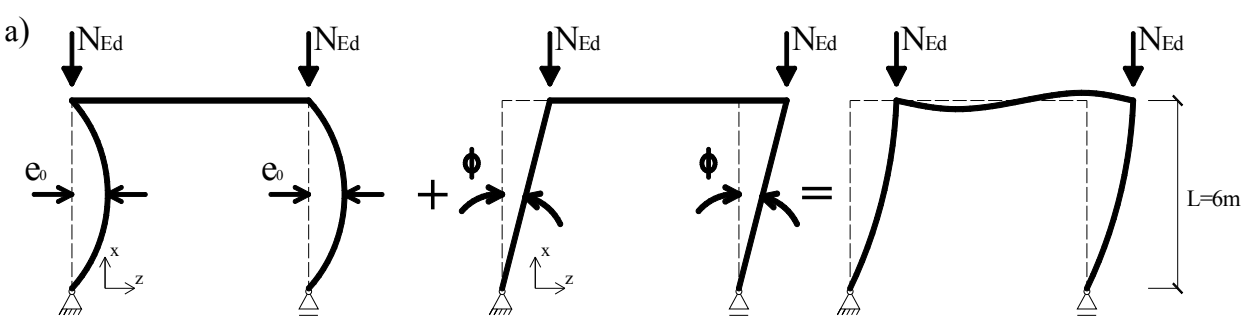

b)
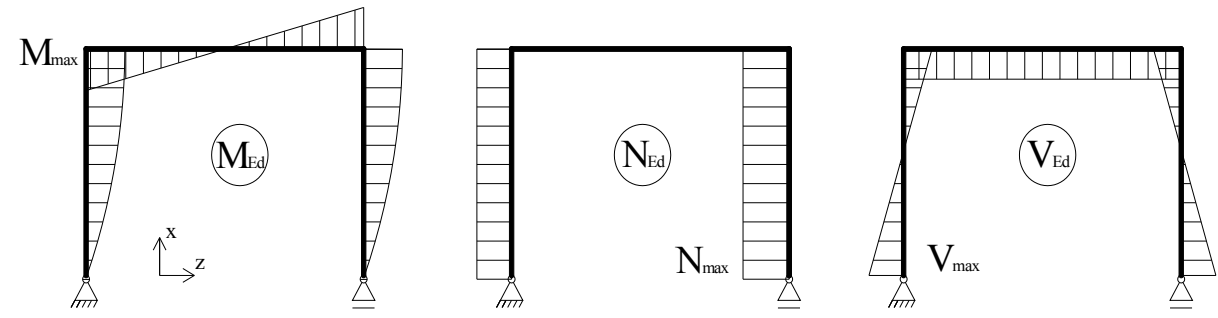

Rys. 6. Analiza II rzędu ramy; a) imperfekcje globalne i lokalne b) wykresy sił wewnętrznych

Fig. 6. The second-order analysis; a) global and local imperfections, b) internal forces diagram

\subsection{Wyniki}

Otrzymane rezultaty, w formie zestawienia współczynników wykorzystania nośności uzyskanych dwoma podejściami obliczeniowymi $\eta_{\mathrm{AVA} 0}$ oraz $\eta_{\mathrm{AVA} 2}$, przedstawiono na rys. 7 .

Podobnie jak w przypadku analizy pojedynczych prętów, dla podejścia obliczeniowego AVA0 decydującym warunkiem obliczeniowym okazała się nośność słupa na wyboczenie (4). W podejściu obliczeniowym AVA2 decydował warunek nośności przekroju przy ściskaniu (1) przy niedużym poziomie wytężenia słupa (siłą obciążająca słup z przedziału $\mathrm{N}_{\mathrm{Ed}}=25 \div 250 \mathrm{kN}$ ) i warunek nośności przekroju na zginanie $\mathrm{z}$ uwzględnieniem siły podłużnej, dla sił o większych wartościach.

Przy zbliżaniu się do największego obliczeniowego wytężenia, podejście AVA2 dawało rezultaty szacowania nośności niższe o ok. $20 \% \mathrm{w}$ stosunku do AVA0. Istotna różnica $\mathrm{w}$ otrzymywanych wytężeniach przekroju nastąpiła w przypadku projektowania na przeciętny stopień wykorzystania nośności równy $\eta_{\mathrm{AVA}, \mathrm{y}}=0,8$. Odpowiadająca mu wartość według podejścia AVA2 wynosi tylko $\eta_{\mathrm{AVA}, \mathrm{y}}=0,2$. 


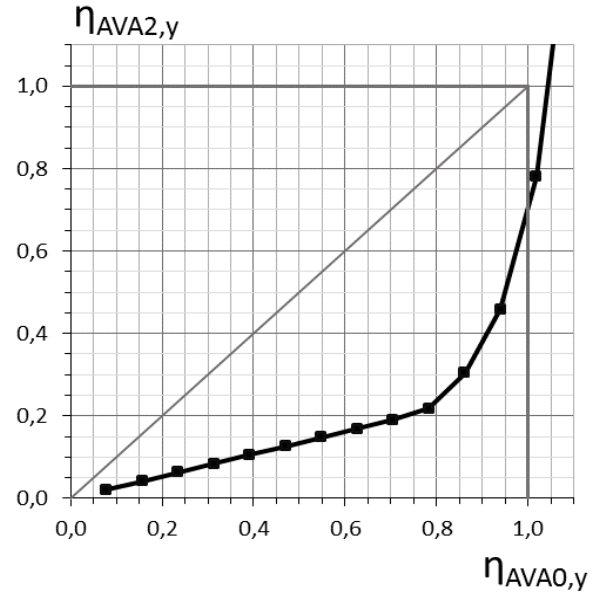

Rys. 7. Porównanie otrzymanych wyników dla układu ramowego

Fig. 7. Comparison obtained results for portal frame

\section{Podsumowanie}

Współczesne normy projektowania pozwalają na różne metody weryfikacji obliczeniowych warunków nośności prętów poddanych ściskaniu, w zależności od poziomu przeprowadzonej wcześniej analizy. Pierwsze podejście obliczeniowe polegało na wyznaczeniu sił wewnętrznych w prętach za pomocą analizy I rzędu, bez uwzględnienia imperfekcji, a weryfikacja nośności polegała na sprawdzeniu obliczeniowych warunków nośności przekroju oraz stateczności ogólnej. Drugim podejściem było uwzględnienie wpływu imperfekcji (globalnej i lokalnych) oraz przeprowadzenie analizy sprężystej według teorii II rzędu. W tym przypadku weryfikacja nośności polega na sprawdzeniu tylko nośności obliczeniowej przekroju.

W referacie poddano porównaniu obliczeniowe wartości wytężenia pojedynczych prętów i układu ramowego uzyskane odmiennymi podejściami obliczeniowymi. Przy stosunkowo niewielkich poziomach wytężenia występują znaczne różnice pomiędzy rezultatami osiąganymi za pomocą tych dwu odmiennych podejść. Przy poziomach wytężenia zbliżających się do $100 \%$ obliczeniowego wykorzystania nośności, otrzymano bardzo dużą zbieżność wyników. 


\title{
Literatura
}

[1] Giżejowski M.: Modele obliczeniowe i metody analizy. XXVII Ogólnopolskie Warsztaty Pracy Projektanta Konstrukcji, Szczyrk, 7-10 marca 2012, t.1, s. 727-766.

[2] PN-EN 1993-1-1 Projektowanie konstrukcji stalowych. Część 1-1: Reguły ogólne i reguły dla budynków. PKN, 2006.

[3] PN-EN 1993-1-6 Projektowanie konstrukcji stalowych. Wytrzymałość i stateczność konstrukcji. PKN, 2009.

[4] PN-EN 1990 Podstawy projektowania konstrukcji. PKN, 2004.

[5] Boissonnade N., et al.: Rules for Member Stability in EN 1993-1-1: Background documentation and design guidelines. ECCS, 2006

[6] Autodesk Robot Structural Analysis Professional, 2013.

\section{THE STABILITY VERIFICATION OF AXIALLY COMPRESSED ELEMENTS BY ADVANCED ANALYSIS}

\begin{abstract}
S u m m a r y
Modern structural codes enable load-bearing verification of axial compressed columns using different approaches. Traditional way is based on individual stability verification, with the use appropriate buckling length, obtained from global mode of instability. First-order, linear analysis (LA) without imperfections is used to predict internal forces in this case. Such approach is named as AVA0. Another way is based on incorporation of imperfections (global sway imperfections and local out-of-straightness imperfections) and providing calculation according to second-order theory. If second order effects in individual members and relevant member imperfections are totally accounted for in the global analysis of the structure, no individual stability check for the members is necessary. This analysis is named as GNIA and the way verification as AVA2.

Nowadays, this approach is more popular because of constant development of computer calculation packages. But there is no information available containing comparison these described above two methods.

The paper presents verification of resistance and stability of axial compressed elements and portal frame done by these two methods. Considered elements were varied in support conditions, slenderness and type of cross-section. In the case of analysed portal frames, slenderness was constant whereas value of load treated as a variable. The relation between types of used method, calculation model and receive results were presented.
\end{abstract}

Keywords: first-order analysis, second-order analysis, global and local imperfections, stability criterion of compressed elements, portal frame

Przestano do redakcji:30.05.2015

Przyjęto do druku:10.01.2016

DOI: $10.7862 / \mathrm{rb} .2015 .180$ 